\title{
New input to the knowledge of the liverwort flora of Amur Province (the Russian Far East)
}

\author{
(C) V.A. Bakalin ${ }^{1}$, T.V. Stupnikova ${ }^{2}$, K.G. Klimova ${ }^{1}$ \\ ${ }^{I}$ Botanical Garden-Institute FEB RAS, Vladivostok, Russia \\ ${ }^{2}$ Amur Branch of the Botanical Garden-Institute FEB RAS, Blagoveshchensk, Russia \\ E-mail:vabakalin@gmail.com,stupnikovat@yandex.ru,ksenia.g.klimova@mail.ru
}

\begin{abstract}
As a result of the short exploration of xeric habitats in the southern part of Amur Province 28 species of liverworts were reveled, with 13 of which are newly found in the province. The annotated list of species, brief note on study area and discussion are provided. The most of revealed taxa are characterized by xerophytic and meso-xerophytic ecology. A number of regionally rare species was recorded in "Sergeevskiy Utyos" Nature Geological Monument that also suggests the floral peculiarity of this protected area. The results obviously show the imperfectness of the available data on liverwort flora of Amur Province and further purposeful researches in this field should be organized.
\end{abstract}

Keywords : Russian Far East, Amur Province, liverworts, rare species, East Asia.

The liverwort flora of Amur Province still lies out of deep interest of students of hepaticology and only a few is known about this land that is diverse in different senses: climatic, geological and phytogeographical. A few scattered literature records of solitary taxa are hardly supplemented by three papers providing likely imperfect information on liverwort diversity in local floras: 34 taxa are recorded for Khingan Nature Reserve (Gambaryan, Cherdantseva, 1998), 24 taxa - for the north-westernmost extreme of the province (Bakalin, 2004) and 50 species for Zeysky Nature Reserve (Abramova, Petelin, 1981; Abramova, Bakalin, 2002). Within recent years large set of liverwort specimens was collected in Tukuringra Range by S.V. Dudov (MW). However, the latter collection is only partly identified and nowhere published. Fortunately, Amur Branch of the Botanical Garden-Institute of Far Eastern Branch of RAS had held the fifth conference "Plants in monsoon climate" in 2018. The conference was supplemented by two short excursions to adjacent areas near Amur River and lower course of Bureya River. Originally organizers planned to show dry vegetation complexes in the easily accessible areas, where the liverwort composition was expected to be somewhat peculiar, although not taxonomically rich. Indeed, we collected rather limited number of specimens containing 28 liverwort taxa, including 13 species newly found in Amur Province. The record of 15 other species also makes the contribution to the knowledge of liverwort distribution in Amur Province if to take into account that only superficial knowledge on the liverwort flora is available. To describe these records is the main goal of the present account.

\section{Material and Methods}

All collections mentioned in the present account were made within four days at the end of September of 2018 in the southern part of the province. In total 56 bryophyte specimens were collected by V.A. Bakalin (with the exception of Porella obtusata f. macrolo$b a$ that was gathered by P.V. Krestov, as discussed by Bakalin \& Klimova, 2019), including 40 liverwort specimens. All collection localities are described in the Table 1 and placed in the Figure 1.

All collected materials are in VBGI, whereas label information is available via online Herbarium Database (http://botsad.ru/herbarium/). 


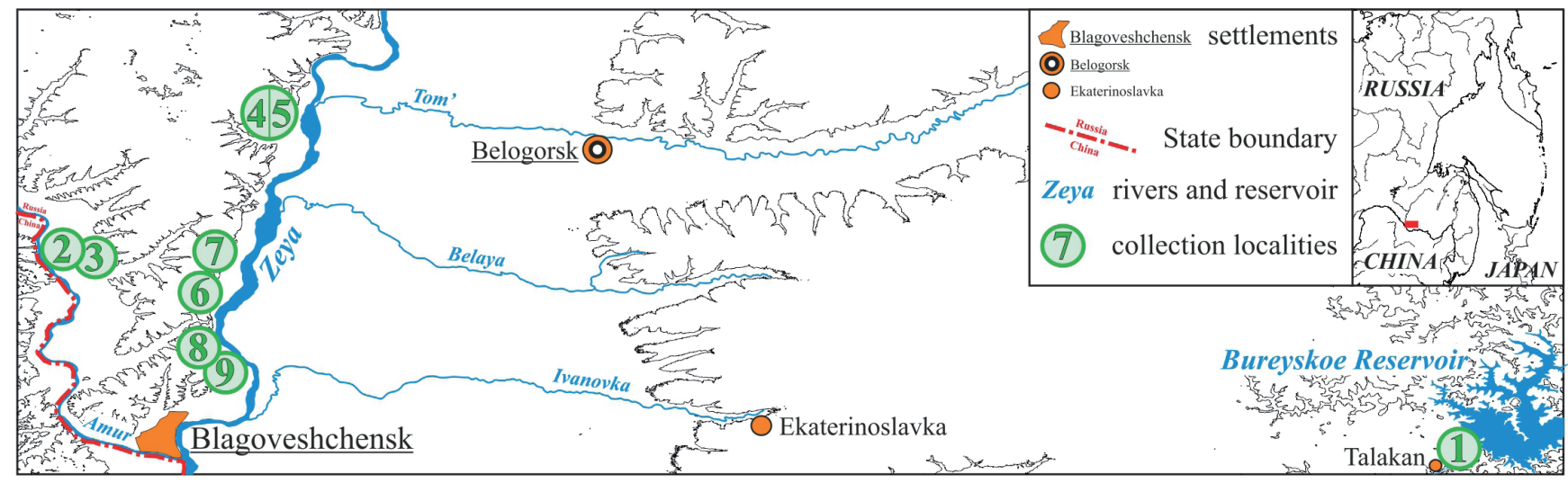

Figure 1. Schematic map of study area in Amur Province with collection localities of liverworts (isohypses are given every 100 meters).

Рисунок 1. Карта-схема района исследований в Амурской области с указанием точек сбора печеночников (горизонтали даны через 100 метров).

Table 1. The list of collection localities in Amur Province (in accordance with Figure 1)

Таблица 1. Список точек сбора на территории Амурской области (в соответствии с Рисунком 1)

\begin{tabular}{|c|c|c|c|c|}
\hline $\begin{array}{l}\text { Locality } \\
\text { (точка сбора) }\end{array}$ & Locality description (описание точки сборов) & $\begin{array}{l}\text { Coordinates } \\
\text { (координаты) }\end{array}$ & $\begin{array}{c}\text { Elevation, m a.s.l. } \\
\text { (высота, м над ур.м.) }\end{array}$ & $\begin{array}{l}\text { Collecting date } \\
\text { (дата сбора) }\end{array}$ \\
\hline 1 & $\begin{array}{l}\text { Bureysky District, } 4 \mathrm{~km} \text { SSE of Talakan Settlement, middle course of } \\
\text { Bureya River, secondary forest with rocky outcrops }\end{array}$ & $\begin{array}{l}50^{\circ} 15^{\prime} 49.5^{\prime \prime} \mathrm{N} \\
130^{\circ} 177^{\prime} 31.3 " \mathrm{E}\end{array}$ & 145 & 20.IX.2018 \\
\hline 2 & $\begin{array}{l}\text { Blagoveshchensky District, } 6 \mathrm{~km} \text { southward of Sergeevka Settlement, right } \\
\text { bank of Glukhaya former river bed (Amur River flood plain), "Sergeevsky } \\
\text { Utyos" Nature Monument, W-facing rocky outcrops }\end{array}$ & $\begin{array}{l}50^{\circ} 41^{\prime} 27.2^{\prime \prime} \mathrm{N} \\
127^{\circ} 20^{\prime} 17.1^{\prime \prime} \mathrm{E}\end{array}$ & 146 & 22.IX.2018 \\
\hline 3 & $\begin{array}{l}\text { Blagoveshchensky District, Sergeevka Settlement surroundings, } \\
\text { agricultural field }\end{array}$ & $\begin{array}{l}50^{\circ} 41^{\prime} 12.7^{\prime \prime} \mathrm{N} \\
127^{\circ} 22^{\prime} 03.0^{\prime \prime} \mathrm{E}\end{array}$ & 182 & 22.IX.2018 \\
\hline 4 & $\begin{array}{l}\text { Blagoveshchensky District, } 96 \mathrm{~km} \text { of hwy. Blagoveshchensk-Svobodny, } \\
4.5 \mathrm{~km} \text { northward of Natal'ino Settlement, swampy massif in flood plain in } \\
\text { Zeya River lower course }\end{array}$ & $\begin{array}{l}51^{\circ} 01^{\prime} 28.5^{\prime \prime} \mathrm{N} \\
127^{\circ} 49^{\prime} 56.5^{\prime \prime} \mathrm{E}\end{array}$ & 200 & 22.IX.2018 \\
\hline 5 & $\begin{array}{l}\text { Blagoveshchensky District, } 96 \mathrm{~km} \text { of hwy. Blagoveshchensk-Svobodny, } \\
4.5 \mathrm{~km} \text { northward of Natal'ino Settlement, steep slope to Zeya River in its } \\
\text { lower course }\end{array}$ & $\begin{array}{l}51^{\circ} 01^{\prime} 28.5^{\prime \prime} \mathrm{N} \\
127^{\circ} 49^{\prime} 56.5^{\prime \prime} \mathrm{E}\end{array}$ & 254 & 22.IX.2018 \\
\hline 6 & $\begin{array}{l}\text { Blagoveshchensky District, Mukhinka Settlement surroundings, } \\
\text { "Mukhinka" Nature Monument, Pinus forest on steep slope }\end{array}$ & $\begin{array}{l}50^{\circ} 32 ' 27.7^{\prime \prime} \mathrm{N} \\
127^{\circ} 38^{\prime} 52.5^{\prime \prime} \mathrm{E}\end{array}$ & 216 & 23.IX.2018 \\
\hline 7 & $\begin{array}{l}\text { Blagoveshchensky District, right bank of Bezymyannaya River, Quercus } \\
\text { forest on slope to small tributary of Zeya River }\end{array}$ & $\begin{array}{r}50^{\circ} 35^{\prime} 10.4^{\prime \prime} \mathrm{N} \\
127^{\circ} 39^{\prime} 41.1^{\prime \prime} \mathrm{E}\end{array}$ & 131 & 23.IX.2018 \\
\hline 8 & $\begin{array}{l}\text { Blagoveshchensky District, Zeya River lower course ca. } 1.1 \mathrm{~km} \text { westward } \\
\text { of Belogor'ye Railway Station, right bank of Zeya River with bedrock } \\
\text { outcrops, small stream valley, Quercus dominated forest }\end{array}$ & $\begin{array}{r}50^{\circ} 26^{\prime} 30.9^{\prime \prime} \mathrm{N} \\
127^{\circ} 40^{\prime} 53.7^{\prime \prime} \mathrm{E}\end{array}$ & 147 & 24.IX.2018 \\
\hline 9 & $\begin{array}{l}\text { Blagoveshchensky District, Zeya River lower course ca. } 2 \mathrm{~km} \mathrm{SSE} \mathrm{of} \\
\text { Belogor'ye Railway Station, right bank of Zeya River with bedrock out- } \\
\text { crops, sandstone outcrops surrounded by Quercus dominated forest }\end{array}$ & $\begin{array}{l}50^{\circ} 25^{\prime} 55.2^{\prime \prime} \mathrm{N} \\
127^{\circ} 42^{\prime} 36.3^{\prime \prime} \mathrm{E}\end{array}$ & 122 & 24.IX.2018 \\
\hline
\end{tabular}

\section{St udy a re a}

The study area is located in the southern part of the Amur-Zeysky Plain and is characterized by an ultra-continental climate with some features of monsoon circulation of air masses. The mean annual temperature is near $0^{\circ} \mathrm{C}$. The duration of the season of active vegetation (with daily mean temperature above $5^{\circ} \mathrm{C}$ ) is $160-170$ days; and the period of active temperatures (daily mean temperature above $10^{\circ} \mathrm{C}$ ) is 134 days. The total solar radiation reaches $115 \mathrm{kcal} / \mathrm{cm}^{2}$ per year, and the sum of the active temperatures is more than $2200^{\circ}$. The absolute temperature minimum and maximum are $-42^{\circ} \mathrm{C}$ and $+41^{\circ} \mathrm{C}$ correspondingly (according to the data of the meteorology station in Yuzhnaya Sergeevka Settlement). The average annual precipitation is about $600 \mathrm{~mm}$, of which only $8 \%$ of the annual amount falls in the cold period (from November to March) and therefore is represented by snow. On the contrary, $92 \%$ of precipitation falls in the warm period (from April to October) and is represented by rains. During the warm season, precipitation distribution is highly uneven: the spring and the first half of summer are usually dry, while the second half of 
summer houses about $50 \%$ of the annual precipitation, mostly taking a form of heavy rains (due to cyclones going from the Pacific). The minimal precipitation is observed in January ( $4.1 \mathrm{~mm}$ per month), and the maximum is observed in July (126.4 mm per month) (Bereznikov, 1973; Korotaev, 1994).

In geomorphological terms, the study area may be called as an accumulative hilly terrace-like plain with absolute elevations less than $260 \mathrm{~m}$ a.s.l. and is composed by a continental sediments of the Triassic - Lower Cretaceous Periods and effusive rocks (of probably aerial formation). During the lower Mesozoic era, the territory of the modern plain was an area of intense subsidence. Due to intensive accumulation the sediments stratum of this period reached a thickness up to $900 \mathrm{~m}$. Later, in the course of Cimmerian Orogeny (much of the Jurassic Period), the land surface was transformed into gentle folds. There was a break in sedimentation in the Upper Cretaceous and Paleogene, whereas in Neogene and Quaternary Periods, the plain is again the place of deposits accumulation. By now, the terrigenous sedimentary continental deposits prevail here and are represented by sandstones, siltstones, argillites. The effusive rocks of basic, neutral and acid composition (of probably Miocene epoch) are less common. There are no rocks of halogenous and carbonate formations. The thickness of deposits of the Cenozoic era increases from north to south and reaches $25 \mathrm{~m}$ thick in the North to $100 \mathrm{~m}$ in the South and reflect intense subsidence of the plain during the lower Cenozoic changed for relatively slow rise in the Pleistocene and Holocene (Voskresensky, 1973).

The more geomorphologic details are available for three localities mentioned in the present account. A relief of the Mukhinka Settlement surroundings (locality 6 of the area) is the formation of parallel ridges with many valleys and took its shape in the Holocene due to landslide processes as well as due to right-handed displacement of Zeya River. As a result of the latter process the asymmetric valley was formed with steep (sometimes over $30^{\circ}$ ) right bank of the river that reaches a height of $130 \mathrm{~m}$ a.s.l. and represents various layers many of which are by sand that is alternated by pebble and dense clays (Darman, Streltsov, 2002).

The geological basis of the "Sergeyevskiy Utyos" Nature Monument (localities 2 and 3 in the studied area) was formed in the Lower Cretaceous Period (ca. 115 million years BP). This is variety of rocky cliffs about $30 \mathrm{~m}$ high on the left bank of the Amur River, interrupted by cracks and faults. These rocks are of volcanic-sedimentary origin and includes tufa, porphyries, keratophyres, tufaceous sandstones and tufa aleurites (Melnikov et al., 2012).
The study area is located in the transitional zone between cool-temperate and hemiboreal vegetation zones represented here by broad-leaved and coniferous and coniferous-deciduous (mixed) forests respectively. The forests with the Pinus sylvestris L. dominance are sparsely distributed and represent the remnants of original 'larch-pine taiga', which was widespread in the earlier phases of the Holocene in the southern half of Amur Province. Forests dominated by Quercus mongolica Fisch. ex Ledeb. are probably of dual origin. Some of them are merely virgin and emerged as an independent formation from the arcto-tertiary ('arctoboreal') forests in the dry beginning of Quaternary period. Other oak communities (more widely distributed here) are the derivatives (of mostly human-induced origin) of after-fire transformation of the vegetation originally dominated by pine (Dobrynin, 2000). Small-leaved forests dominated by Betula platyphylla Sukaczev and Populus tremula L. are of secondary origin and are not associated with any original formation.

Shrubby, meadow (grass-forb, and sedge-Calamagrostis communities) and marsh vegetation communities, fragments of forests with the participation of Salix, Populus, Alnus hirsuta (Spach) Rupr., Ulmus japonica (Rehder) Sarg., Phellodendron amurense Rupr. are distributed in the flood plains and wide river valleys. Grass-forb associations of steppe communities distributed fragmentarily, mainly along floodplain terraces of the second and third levels, as well as on rocks and rocky slopes in the Amur and Zeya River valleys. We had the chance to investigate the aforementioned rocks and rocky slopes in several localities (most extensive are in localities 1 and 2). Since they house rare vascular plant xerophytes (Kuznetsova, 2009) known in Amur Province from single localities: Selaginella tamariscina (Beauv.) Spring, Aleuritopteris argentea (S.G. Gmel.) Fee, Potentilla verticillaris Stephan ex Willd., Aquilegia atropurpurea Willd., Stellera chamaejasme L., including probable relics of the Pliocene forest-steppe formation: Diarthron linifolium L., Gueldenstaedtia verna (Georgi) Boriss. (Polozhiy, 2001), we expected some rare liverwort xerophytes here.

\section{Annotated list}

The collected taxa are arranged alphabetically, where nomenclature of taxa is mostly followed to Konstantinova et al. (2009), with one exception for Trocholejeunea sandvicensis (Gotsche) Mizut. that was transferred by Wang et al. (2014) to Acrolejeunea basing on molecular-genetic research and therefore, mentioned in our list as A. sandvicensis. The each species name is supplemented by: 1) presence of gen- 
erative organs or vegetative propagules, with abbreviations (ant. - antheridia, arch. - archegonia, per. perianths, spor. - sporogonia, gemm. - gemmae); 2) the locality number (corresponding to Table 1 and Figure 1); 3) generalized habitat description; 4) field number of the specimen. The taxa previously recorded for Amur Province are supplemented with corresponding literature reference. New records for the province are marked by asterisk (*).

Acrolejeunea sandvicensis (Gottsche) Steph. per. -2 - Open dry cliffs. In pure mat or mixed with Reboulia hemisphaerica (L.) Raddi subsp. orientalis. Am-63-9-18, Am-63-18-18 (VBGI). Recorded for Khingan Nature Reserve (Gambaryan, Cherdantseva, 1998).

Cephalozia bicuspidata (L.) Dumort. - gemm. 4 - Open hummocks in the sedge-Sphagnum swamp disturbed by fire. With Calypogeia muelleriana (Schiffn.) Müll. Frib. Am-65-1-18 (VBGI). Recorded for Zeysky Nature Reserve (Abramova, Bakalin, 2002) and Udokan Range in the North-Western part of the province (Bakalin, 2004).

*Cephaloziella divaricata (Sm.) Schiffn. - ant., arch. -2 - Open mesic cliff. In pure mat. Am-63-1-18 (VBGI).

*Chiloscyphus polyanthos (L.) Corda - per., ant. $-8-$ Partly shaded moist humus and sandy soil near stream. In pure mat. Am-69-4-18, Am-69-8-18 (VBGI).

* Clevea nana (Shimizu \& S. Hatt.) Borovich. \& Bakalin - spor. - 2 - Open mesic cliff crevice filled with fine soil and humus. With Mannia fragrans (Balb.) Frye \& L. Clark, Reboulia hemisphaerica (L.) Raddi. Am-63-3-18, Am-63-12-18 (VBGI).

*Frullania cf. muscicola Steph. - per. - 6 - Living Quercus mongolica trunk in part shade in Quercus forest at ridgeline. In pure mat. Am-67-1-18. This specimen was recently re-studied by Yu.S. Mamontov and referred to potentially new species for science, which he intend to describe in the future. Currently, the specimen is present in the online herbarium database (http://botsad.ru/herbarium/), but is physically absent in the herbarium (VBGI) and its location is not known.

Fuscocephaloziopsis pleniceps (Austin) Váňa \& L. Söderstr. - ant., arch. - 4-Open hummocks in the sedge-Sphagnum swamp damaged by fire. In pure mat. Am-65-2-18 (VBGI). Recorded for Zeysky Nature Reserve (Abramova, Bakalin, 2002).

Harpanthus scutatus (F. Weber \& D. Mohr) Spruce -8 - Partly shaded moist humus near stream. In pure mat. Am-69-3-18 (VBGI). Recorded for Khingan Nature Reserve (Gambaryan, Cherdantseva, 1998).
*Jungermannia pumila With. - per., ant. - 9 Open mesic sandstone cliffs on slope to river. In pure mat. Am-70-1-18 (VBGI).

Liochlaena subulata (A. Evans) Schljakov gemm. $-7,8$ - Open to partly shaded moist sandy slope to the stream and sandy-clayish soil on the path in Quercus forest. In pure mats or with Lophocolea heterophylla. Am-69-1-18, Am-69-8a-18, Am-6910-18 (VBGI). Recorded for Zeysky Nature Reserve (Abramova, Bakalin, 2002).

Lophocolea heterophylla (Schrad.) Dumort. per., ant. -8 - Partly shaded moist humus near stream. In pure mats or with Liochlaena subulata. Am-691-18, Am-69-2-18 (VBGI). Recorded for Khingan Nature Reserve (Gambaryan, Cherdantseva, 1998) and for Zeysky Nature Reserve (Abramova, Bakalin, 2002).

Lophocolea minor Nees - gemm. - 9 - Open mesic sandstone cliffs on slope to river. In pure mat. Am-70-2-18 (VBGI). Recorded for Khingan Nature Reserve (Gambaryan, Cherdantseva, 1998) and for Zeysky Nature Reserve (Abramova, Bakalin, 2002).

Mannia androgyna (L.) Evans - ant., arch. - 2 Open mesic cliff crevice filled with fine soil and humus. With Mannia triandra (Scop.) Grolle. Am-632a-18 (VBGI). Recorded for middle course of Bureya River (Ellis et al. 2013).

Mannia fragrans (Balb.) Frye \& L. Clark spor. - 1, 2, 7, 9 - Open mesic sandstone cliffs and their crevices filled with fine soil and humus; open, mesic sandy soil on steep slope in Quercus forest. In pure mats or with Mannia androgyna, Riccia sorocarpa. Am-63-2-18, Am-63-6-18, Am-63-14a-18, Am-68-2-18, Am-70-3-18 (VBGI). Recorded for lower course of Bureya River (Gambaryan, 2000).

*Mannia triandra (Scop.) Grolle - spor., ant. - 2, 5 - Open mesic cliff crevice filled with fine soil and humus; sandy soil along roadside in Pinus sylvestris forest. With Mannia androgyna. Am-62-2-18, Am66-1-18 (VBGI).

Pedinophyllum truncatum (Steph.) Inoue - per., ant. -9-Partly shaded moist humus in steep slope. In pure mat. Am-70-8-18 (VBGI). Recorded for Khingan Nature Reserve (Gambaryan, Cherdantseva, 1998).

*Pellia neesiana (Gottsche) Limpr. - ant. - 8 Partly shaded moist humus near stream. In pure mat. Am-69-1-18 (VBGI).

*Plagiochasma japonicum (Steph.) C. Massal. spor., ant. - 1 - Open mesic to dry cliff crevices filled with clayish soil. In pure mat. Am-62-1-18 (VBGI).

Plagiochila porelloides (Torr. ex Nees) Lindenb. - per. -8 - Open to partly shaded moist sandy slope to the stream. In pure mat. Am-69-7-18 (VBGI). Recorded for Zeysky Nature Reserve (Abramova, 
Bakalin, 2002) and for Khingan Nature Reserve (Gambaryan, Cherdantseva, 1998).

Porella obtusata (Taylor) Trevis. f. macroloba (Steph.) S. Hatt. - 2 - Open mesic cliff crevice filled with fine soil and humus. With Mannia fragrans. Am63-5-18, Am-63-14-18 (VBGI). Recorded as new for Russia from this site by Bakalin \& Klimova (2019).

Ptilidium ciliare (L.) Hampe - 8 - Partly shaded moist fallen decaying tree trunk near stream. In pure mat. Am-69-6-18 (VBGI). Recorded for Zeysky Nature Reserve (Abramova, Bakalin, 2002) and for Udokan Range (Bakalin, 2004).

Reboulia hemisphaerica (L.) Raddi subsp. hemisphaerica - ant., arch., spor. - 2, 8- Open mesic cliff crevice filled with fine soil and humus; partly shaded moist humus near stream. In pure mats. Am-63-11-18, Am-69-5-18, Am-69-9-18 (VBGI). Recorded without identification of the subspecies for Udokan Range (Bakalin, 2004).

*Reboulia hemisphaerica (L.) Raddi subsp. orientalis R.M. Schust - ant., arch. - 2 - Open dry cliffs and mesic cliff crevice filled with fine soil and humus. In pure mats or with Acrolejeunea sandvicensis. Am63-7-18, Am-63-9-18, Am-63-13-18, Am-63-19-18 (VBGI).

*Riccia beyrichiana Hampe ex Lehm. - spor. 3 - Moist clayish soil at the edge of agricultural field. With Riccia sp. Am-64-1-18 (VBGI).

*Riccia bifurca Hoffm. - spor. - 2 - Open mesic cliff crevice filled with fine soil and humus. With Riccia sorocarpa. Am-63-8-18 (VBGI).

Riccia fluitans L. -7 - Open wet humus along river course, among Carex hummocks. Am-68-3-18, Am-68-4-18 (VBGI). Recorded for lower course of Bureya River (Gambaryan, 2000).

*Riccia sorocarpa Bisch. - spor. - 2 - Open mesic cliff crevice filled with fine soil and humus. In pure mats or with Riccia bifurca, Mannia fragrans. Am-63-4-18, Am-63-6-18, Am-63-8-18, Am-63-8a-18 (VBGI).

*Targionia hypophylla L. - spor. - 1, 2, 8-Open mesic to dry cliff crevices filled with clayish soil and humus; partly shaded moist humus near stream. In pure mats. Am-62-3-18, Am-63-10-18, Am-69-5a-18 (VBGI).

\section{D i s c us sion}

The main result, as it could be seen from this list, is the clear evidence of poor knowledge on liverwort flora of Amur Province in general. Indeed, 13 taxa were newly recorded for the province in the course of hardly purposeful 4-days collecting in the driest areas. It is unclear why such taxa as Clevea nana, three meso-xerophytic species of Riccia, Targionia hypophylla, Plagiochasma japonicum, all of those should be quite abundant in these dry areas, were not recorded before despite the long and purposeful study of Khingan Nature Reserve liverworts by professional hepaticologist (S.K. Gambaryan in Gambaryan, Cherdantseva, 1998).

The highest specificity was found in "Sergeevskiy Utyos" Nature Geological Monument, where we found five taxa only, with four of them were new records for Amur Province. This may confirm the high relationship of taxonomic specificity of liverwort floras with the substrate characteristic. Another reason may be the relict occurrence of some taxa in this nature monument representing geologically ancient and unique formation (Melnikov et al., 2012).

The most 'bright' record in the studied collection is Porella obtusata f. macroloba - an obvious relict there, which area core covers dry habitats in Sino-Himalayan region (type form, which may represent other taxon of the species level, is distributed in Europe). This record was earlier discussed by Bakalin \& Klimova (2019). Other 'interesting' records of taxa include Clevea nana - hemiboreal-cool-temperate East Asian species. It is restricted in Russia to several localities in Primorsky Territory, one locality near Chita City surroundings (Zabaykalsky Territory, cf. Borovichev, Bakalin 2013) and one locality in Balagan Mt. (Sakhalin Island, Bakalin et al., in print). Borovichev and Bakalin (2013) reported the species from Chukotka Autonomous District, but we doubt this report that should be highly enigmatic from the phytogeographical point of view.

The record of Riccia beyrichiana - a subcircumpolar temperate taxon - fills the gap in the distribution of this taxon in Asia, where it was before known from three regions: Altay Territory westward and from the Primorsky Territory and Japan eastward (Borovichev, Bakalin, 2016).

Unlike to four taxa mentioned above, other new records for Amur Province could be likely expected before, if the general distribution of the taxa would be taken into account.

\section{Acknow ledgem ents}

This work was done only due to short post-conference field trip nicely organized by Amur Branch of the Botanical Garden-Institute administration, to that authors are sincerely grateful. The work of Bakalin and Klimova was partially supported by the Russian Foundation for Basic Researches (grant number 17-04-00018). Authors are deeply indebted to anonymous reviewers and Dr. V. Barkalov (VLA) for constructive recommendations for the preparation of the present account. 


\section{References}

Abramova L.I., Bakalin V.A. 2002. O flore pechyonochnikov Zeiskogo zapovednika (Amurskaya Oblast) [On the flora of Hepaticae of Zeya Nature Reserve (Amur Province)]. Byull. Moskovsk. Obshch. Isp. Prir., Otd. Biol. 107(2): 65-67. (In Russ.)

Abramova L.I., Petelin D.A. 1981. Mokhoobraznyye [Bryophytes]. In: Flora $i$ rastitelnost khrebta Tukuringra (Amurskaya Oblast) [Flora and vegetation of Tukuringra Range (Amur Province)]. Moscow. 64-85 pp. (In Russ.)

Bakalin V.A. 2004. Hepatics of Stanovoye Nagor'e Uplands (Eastern Siberia). Arctoa. 13: 73-83. (in Russ. with Engl. summary) doi 10.15298/arctoa.13.10

Bakalin V.A., Klimova K.G. 2019. Porellaceae (Hepaticae) in the Russian Far East. Botanica Pacifica. 8(1): 105-131. DOI: 10.17581/bp.2019.08110

Bakalin V.A., Korznikov K.A., Klimova K.G. 2019. To the knowledge of liverwort flora of Balagan Mountain and Vengeri River Valley (Sakhalin Island, North-West Pacific). Bulletin of the BGI FEB RAS. Vol. 22. 15-27 pp. DOI: 10.17581/bbgi2202 (in Engl. with Russ. summary)

Bereznikov K.P. (ed.). 1973. Agroklimaticheskiye resursy Amurskoi Oblasti [Agroclimatic resources of the Amur Province]. Leningrad. 104 pp. (In Russ.)

Darman Yu.A., Streltsov A.N. (eds.). 2002. Prirodnyye kompleksy urochishcha "Mukhinka" [Natural complexes of the "Mukhinka" area]. Blagoveshchensk. 172 pp.

Borovichev E.A., Bakalin V.A. 2013. The Survey of Marchantiales from the Russian Far East I. The Review of Cleveaceae (Hepaticae). Botanica Pacifica. 2(1): 53-61. DOI: $10.17581 / \mathrm{bp} .2013 .02106$

Borovichev E.A., Bakalin V.A. 2016. Survey of the Russian Far East Marchantiales IV: A revision of Ricciaceae (Hepaticae). Botanica Pacifica. 5(2): 3-29. DOI: 10.17581/ bp.2016.05205

Dobrynin A.P. 2000. Dubovyye lesa rossiiskogo Dalnego Vostoka (biologiya, geografiya i proiskhozhdenie [Oak forests of the Russian Far East (biology, geography and origin)] Vladivostok. 260 pp. (In Russ.)

Dudov S.V., Kozhin M.N., Fedosov V.E., Ignatova E.A., Ignatov M.S. 2018. Moss flora of Zeysky State Nature Reserve (Tukuringra Range, Amur Province, Russia). Botanica Pacifica. 7(2): 83-104. DOI: 10.17581/bp.2018.07204

Ellis L.T., Bakalin V.A., Baisheva E., Bednarek-Ochyra H., Ochyra R., Borovichev E.A., Choi S.S., Sun B.-Y, Erzberger P., Fedosov V.E., Garilleti R., Albertos B., Górski P., Hájková P., Hodgetts N.G., Ignatov M., Koczur A., Kurbatova L.E., Lebouvier M., Mežaka A., Miravet J., Paw- likowski P., Porley R.D., Rosselló J.A., Sabovljević M.S., Pantović J., Sabovljević A., Schröder W., Ştefănuț S., Suárez G.M., Schiavone M., Yayintaş Ö.T. \& Váňa J. 2013. New national and regional bryophyte records, 36. J. Bryol. 35(3): 228-238. https://doi.org/10.1179/1743282013Y.0000000064

Gambaryan S.K. 2000. Dopolneniya k flore pechyonochnikov [Additions to the Hepatic flora]. In: Rasteniya mussonnogo klimata [Plants of monsoon climate]. Vladivostok. 48-49 pp. (In Russ.)

Gambaryan S.K., Cherdantseva V.YA. 1998. Mokhoobraznyye [Bryophytes]. In: Flora i rastitelnost Khinganskogo zapovednika [Flora and vegetation of Khingan Nature Reserve]. Vladivostok. 70-87 pp. (In Russ.)

Konstantinova N.A., Bakalin V.A. with contributions on regional floras from Andrejeva E.N., Bezgodov A.G., Borovichev E.A., Dulin M.V., Mamontov Yu.S. 2009. Checklist of liverworts (Marchantiophyta) of Russia. Arctoa. 18: 1-64. doi 10.15298/arctoa.18.01

Korotaev G.V. 1994. Blagoveshchensk: priroda i ekologia [Blagoveshchensk: nature and ecology]. Blagoveshchensk. 125 pp. (In Russ.)

Kuznetsova E.D. (ed.). 2009. Krasnaya kniga Amurskoi Oblasti: redkiye i nakhodyashchiesya pod ugrozoi ischeznoveniya vidy zhyvotnykh, rastenii $i$ gribov [Red Data Book of Amur Province: rare and endangered species of animals, plants and fungi]. Blagoveshchensk. 446 pp. (In Russ.)

Melnikov A.V., Yusupov D.V., Melnikov V.D. 2012. Geologicheskiye pamyatniki $i$ primechatelnye obyekty prirody Amurskoi Oblasti [Geological monuments and remarkable natural objects of the Amur Province]. Blagoveshchensk. 148 pp.

Polozhiy A.V. 2001. K poznaniyu genezisa stepnoi flory na yuge Prieniseiskoi Sibiri [To the knowledge of genesis of the steppe flora in the south of Yenisei Siberia]. Krylovia. 3(2): 58-62. (In Russ.)

Voskresensky S.S. (ed.). 1973. Geomorfologia Amuro-Zeiskoi ravniny $i$ nizkogorya Malogo Khingana [Geomorphology of the Amur-Zeya plain and low mountains of Malyi Khingan]. Moscow. 274 pp. (In Russ.)

Wang J., Gradstein S.R., Shi X.-Q., Zhu R.-L. 2014. Phylogenetic position of Trocholejeunea and a new infrageneric classification of Acrolejeunea (Lejeuneaceae, Marchantiophyta). Bryophyte Diversity and Evolution. 36(1): 3144. DOI: http://dx.doi.org/10.11646/bde.36.1.3

Zhukova A.L., Preis Yu.I. 1980. K flore pechyonochnykh mkhov basseina reki Burei (Amurskaya Oblast) [To the liverwort flora of Bureya River basin (Amur Province)]. Novosti Sist. Nizsh. Rast. 17: 231-234. (In Russ.) 


\title{
Новые данные к познанию флоры печеночников Амурской области (российский Дальний Восток)
}

\author{
(C) В.А. Бакалин ${ }^{1}$, Т.В. Ступникова ${ }^{2}$ К.Г. Климова ${ }^{1}$ \\ ${ }^{1}$ Ботанический сад-институт ДВО РАН, Владивосток, Россия \\ 2 Амурский филиал ботанического сада-института ДВО РАН, Благовещенск, Россия \\ E-mail:vabakalin@gmail.com,stupnikovat@yandex.ru,ksenia.g.klimova@mail.ru
}

\begin{abstract}
В результате непродолжительного исследования ксерофитных местообитаний в южной части Амурской области было выявлено 28 видов печеночников, 13 из которых приводятся для области впервые. Даны краткое описание района исследований, аннотированный список видов и обсуждение находок. Большая часть из впервые выявленных в области видов являются ксерофитами и мезо-ксерофитами. Ряд видов, новых для области, был обнаружен только в пределах геологического памятника природы регионального значения «Сергеевский утес», что говорит и о флористическом своеобразии этой охраняемой территории. Степень новизны полученных результатов показывает явный недостаток имеющихся данных о флоре печеночников области и необходимость ее дальнейшего целенаправленного исследования.
\end{abstract}

Ключевые слова: российский Дальний Восток, Амурская область, печеночники, редкие виды, Восточная Азия.

\section{Спи сок литературы}

[Abramova, Bakalin] Абрамова Л.И., Бакалин В.А. 2002. О флоре печеночников Зейского заповедника (Амурская область). Бюл. Моск. о-ва испыт. прир. Отд. биол. 107(2): 65-67.

[Abramova, Petelin] Абрамова Л.И., Петелин Д.А. 1981. Мохообразные. В кн.: Флора и растительность хребта Тукурингра (Амурская область). М. C. $64-85$.

[Bakalin] Бакалин В.А. 2004. Печеночники Станового Нагорья. Arctoa. 13: 73-83. doi 10.15298/arctoa.13.10

Bakalin V.A., Klimova K.G. 2019. Porellaceae (Hepaticae) in the Russian Far East. Botanica Pacifica. 8(1): 105131. DOI: $10.17581 /$ bp. 2019.08110

Bakalin V.A., Korznikov K.A., Klimova K.G. 2019. To the knowledge of liverwort flora of Balagan Mountain and Vengeri River Valley (Sakhalin Island, North-West Pacific). Бюллетень Ботанического caда-института ДВО РАН. Вып. 22. С. 15-27. DOI: $10.17581 /$ bbgi2202

[Bereznikov] Березников К.П. (отв. ред.). 1973. Агроклиматические ресурсы Амурской области. Л. 104 с.

Borovichev E.A., Bakalin V.A. 2013. The Survey of Marchantiales from the Russian Far East I. The Review of Cleveaceae (Hepaticae). Botanica Pacifica. 2(1): 53-61. DOI: 10.17581/bp.2013.02106
Borovichev E.A., Bakalin V.A. 2016. Survey of the Russian Far East Marchantiales IV: A revision of Ricciaceae (Hepaticae). Botanica Pacifica. 5(2): 3-29. DOI: $10.17581 /$ bp.2016.05205

[Darman, Streltsov] Дарман Ю.А, Стрельцов А.Н. (ред.). 2002. Природные комплексы урочища «Мухинка». Благовещенск. 172 с.

[Dobrynin] Добрынин А.П. 2000. Дубовые леса российского Дальнего Востока (биология, география и происхождение). Владивосток. 260 с.

Dudov S.V., Kozhin M.N., Fedosov V.E., Ignatova E.A., Ignatov M.S. 2018. Moss flora of Zeysky State Nature Reserve (Tukuringra Range, Amur Province, Russia). Botanica Pacifica. 7(2): 83-104. DOI: 10.17581/ bp.2018.07204

Ellis L.T., Bakalin V.A., Baisheva E., Bednarek-Ochyra H., Ochyra R., Borovichev E.A., Choi S.S., Sun B.-Y, Erzberger P., Fedosov V.E., Garilleti R., Albertos B., Górski P., Hájková P., Hodgetts N.G., Ignatov M., Koczur A., Kurbatova L.E., Lebouvier M., Mežaka A., Miravet J., Pawlikowski P., Porley R.D., Rosselló J.A., Sabovljević M.S., Pantović J., Sabovljević A., Schröder W., Ştefănuţ S., Suárez G.M., Schiavone M., Yayintaş Ö.T. \& Váňa J. 2013. New national and regional bryophyte records, 36. J. Bryol. 35(3): 228-238. https://doi.org/10.1179/1743282013Y.0000000064 
[Gambaryan] Гамбарян C.К. 2000. Дополнения к флоре печеночников. В кн.: Растения муссонного климата. Владивосток. С. 48-49.

[Gambaryan, Cherdantseva] Гамбарян С.К., Черданцева В.Я. 1998. Мохообразные. В кн.: Флора и растительность Хинганского заповедника. Владивосток. C. $70-87$.

Konstantinova N.A., Bakalin V.A. with contributions on regional floras from Andrejeva E.N., Bezgodov A.G., Borovichev E.A., Dulin M.V., Mamontov Yu.S. 2009. Checklist of liverworts (Marchantiophyta) of Russia. Arctoa. 18: 1-64. doi 10.15298/arctoa.18.01

[Korotaev] Коротаев Г.В. 1994. Благовещенск: природа и экология. Благовещенск. 125 с.

[Kuznetsova] Кузнецова Е.Д. (ред.). 2009. Красная книга Амурской области: редкие и находящиеся под угрозой исчезновения виды животных, растений и грибов. Благовещенск. 446 с.
[Melnikov] Мельников А.В., Юсупов Д.В., Мельников В.Д. 2012. Геологические памятники и примечательные объекты природы Амурской области. Благовещенск. 148 с.

[Polozhyi] Положий А.В. 2001. К познанию генезиса степной флоры на юге Приенисейской Сибири. Krylovia. 3(2): 58-62.

[Voskresensky] Воскресенский С.С. (ред.). 1973. Геоморфология Амуро-Зейской равнины и низкогорья Малого Хингана. М. 274 с.

Wang J., Gradstein S.R., Shi X.-Q., Zhu R.-L. 2014. Phylogenetic position of Trocholejeunea and a new infrageneric classification of Acrolejeunea (Lejeuneaceae, Marchantiophyta). Bryophyte Diversity and Evolution. 36 (1): 31-44. DOI: http://dx.doi.org/10.11646/bde.36.1.3

[Zhukova, Preis] Жукова А.Л., Прейс Ю.И. 1980. К флоре печеночных мхов бассейна реки Буреи (Амурская область). Новости сист. низш. раст. 17: 231-234. 